Jurnal Penyuluhan, September 2017 Vol. 13 No. 2

\title{
Kompetensi Pembudidaya Ikan Lele dalam Mengelola Usaha di Muncar, Banyuwangi, Jawa Timur
}

\author{
The Competencies of Freshwater Fish Farmers in Managing \\ the Business in Muncar, Banyuwangi, East Java \\ Ary Bakhtiar ${ }^{1}$, Siti Amanah², Anna Fatchiya ${ }^{2}$ \\ ${ }^{1}$ Jurusan Agribisnis, Fakultas Pertanian - Peternakan, Universitas Muhammadiyah Malang, Malang \\ ${ }^{2}$ Departemen Sains Komunikasi dan Pengembangan Masyarakat, \\ Fakultas Ekologi Manusia, Institut Pertanian Bogor, Bogor
}

\begin{abstract}
The increase in fish production relates to the competencies of the fish farmers. A fish farmer should have specific competencies to run the aqua-culture business including: managerial skills, production skills and marketing skills. The current competencies of fish farmers in the Muncar District are still limited to production skills. This study aims to analyse the factors affect fresh water fish farmer's competencies in managing the business. A survey was conducted from March to April 2016 to gather data from 48 fish farmers in Muncar Banyuwangi. Questionnaire composed of 71 questions about the why fish farmers plan the aquaculture bussines, managerial, feeding, and marketing was used to gather data from the respondents. Semi structured interviews were conducted to collect information from key informans. Data was analysed using a regression model represented that competencies were affected by individual characteristics of the fish farmers, availability of fishery inputs- ouputs and fisheries extension support services. The results show that 1) The fish farmers have a high level of competencies in managerial and production skills, but low competence in bargaining the price with the fish brokers. 2). Factors that are significantly affect the competencies are the number of dependents, availability of fishery inputs- ouputs and fisheries extension support services.
\end{abstract}

Keywords: competencies, fisheries extension, fish farmers

\begin{abstract}
Abstrak
Peningkatan produksi ikan berkaitan dengan kompetensi pembudidaya ikan. Seorang pembudidaya ikan harus memiliki kompetensi khusus untuk menjalankan usaha budaya ikan termasuk: keterampilan manajerial, keterampilan produksi dan keterampilan pemasaran. Kompetensi saat ini petani ikan di Kecamatan Muncar masih terbatas pada kemampuan produksi. Penelitian ini bertujuan untuk menganalisis faktor yang mempengaruhi kompetensi pembudidaya ikan air tawar dalam mengelola usaha. Penelitian Survei dilakukan dari bulan Maret sampai April 2016 untuk mengumpulkan data dari 48 pembudidaya ikan di Muncar Banyuwangi. Kuesioner terdiri dari 71 pertanyaan tentang mengapa pembudidaya ikan merencanakan usaha budidaya, manajerial, pengelolaan pakan, serta pemasaran. Wawancara semi terstruktur dilakukan untuk mengumpulkan informasi dari informan kunci. Data dianalisis dengan menggunakan model regresi dengan model regresi: kompetensi dipengaruhi oleh karakteristik individu pembudidaya ikan, ketersediaan dukungan inputs- ouputsperikanan dan dukungan penyuluhan perikanan. Hasil penelitian menunjukkan bahwa 1) Pembudidaya ikan memiliki tingkat kompetensi yang tinggidalam keterampilan manajerial dan produksi, tetapi masih rendah dalam penentuan harga ikan dengan tengkulak 2). Faktor-faktor yang secara signifikan mempengaruhi kompetensi adalah jumlah tanggungan keluarga, ketersediaan dukungan sarana inputs- ouputs perikanan dan dukungan penyuluhan perikanan.
\end{abstract}

Kata kunci: kompetensi, penyuluhan perikanan, pembudidaya ikan

\section{Pendahuluan}

Ketersediaan sumber daya ikan diharapkan mampu menjadi leading sector perekonomian nasional di era yang akan datang. Saat ini sumberdaya ikan telah menjadi komoditas unggulan (Adam, 2012), seiring dengan perubahan pola konsumsi daging dari pola red meat ke white meat (Kusumastanto, 2008). Sebanyak 57,2\% kebutuhan jumlah konsumsi protein hewani berasal dari ikan, sisanya $23,2 \%$ berasal dari telur serta susu dan daging sebanyak $19,6 \%$, jumlah konsumsi ikan setiap orangnya pada tahun 2008 rata-rata $28 \mathrm{~kg} /$ tahun dan pada tahun 2010 dan 2030 diperkirakan akan naik menjadi $30 \mathrm{~kg} / \mathrm{tahun}$ dan $45 \mathrm{~kg} /$ tahun (Putri, 2014), (Direktorat Jenderal Pengolahan Hasil Perikanan Kementerian Kelautan, 2013). Angka ini menunjukkan bahwa ikan masih menjadi sumber protein yang utama di masyarakat.

Jumlah produksi rata-rata sektor perikanan tangkap pada tahun 2014 adalah sebesar 5.411.677,6 juta ton dengan kenaikan sebesar 3,52\% (LAKIP KKP, 2014). Kebutuhan konsumsi protein hewani 
yang demikian ini, belum dapat dipenuhi jika hanya mengandalkan sektor perikanan tangkap saja. Salah satu upaya yang telah ditempuh oleh Pemerintah yakni dengan optimalisasi sektor perikanan budidaya. Dalam hal ini, Rahmawati dan Hartono (2012) menyatakan bahwa usaha budidaya ikan air tawar berpeluang berkembang lebih besar.

Aprolita et al., (2008) menyatakan bahwa keberhasilan usaha budidaya dapat dilihat langsung pada hasil usaha per masa tanam. Pembudidaya yang kompeten akan mampu mengembangkan usaha yang ditunjukkan oleh kinerja yang tinggi, termasuk hasil budidaya. Kompetensi menurut Spencer dan Spencer (1993) merupakan kondisi fisik (traits) yang merespon secara tepat pada kondisi tertentu berupa perilaku yang diharapkan, termasuk pengetahuan (knowledge) dan keterampilan (skills) yang sesuai luaran kerja yang diharapkan. Hal ini diperkuat Boyatzis (Vazirani, 2010) kompetensi merupakan penekanan dari wujud karakteristik individu seseorang dalam menunjukkan performa kerja yang dapat mencakup watak, kemauan, kemampuan serta norma sosial pada masing-masing individu.

Kabupaten Banyuwangi memiliki potensi perikanan tangkap dan budidaya ikan air tawar. Dalam 5 tahun terakhir sebanyak 35\% nelayan di Kabupaten Banyuwangi khususnya di Kecamatan Muncar beralih profesi menjadi pembudidaya ikan air tawar. Alih profesi ini memerlukan pengembangan keterampilan dalam usaha budidaya ikan. Kemampuan pembudidaya ikan di beberapa wilayah Indonesia masih terbatas oleh berbagai faktor. Hal ini dikemukakan pula oleh Fatchiya (2010). Rendahnya dukungan sarana produksi perikanan (Aprolita et al., 2008), minimnya pelatihan (Widakdo, 2014), terbatasnya penyuluhan(Hariyadi et al., 2014). Tujuan penelitian menganalisis tingkat kompetensi pembudidaya ikan lele dan menganalisisfaktor-faktor yang berpengaruh terhadap kompetensi pembudidaya ikan lele di Kecamatan Muncar Kabupaten Banyuwangi.

\section{Metode Penelitian}

Populasi dalam penelitian adalah seluruh pembudidaya ikan lele (160 orang) di Kecamatan Muncar Kabupaten Banyuwangi Provinsi Jawa Timur. Kecamatan Muncar merupakan sentra usaha budidaya ikan lele jenis dumbo di Banyuwangi. Data lapang dikumpulkan mulai Maret sampai April 2016.
Responden pembudidaya dipilih dari pembudidaya ikan di enam desa di Muncar sejumlah 48 orang. Dari setiap desa dipilih sejumlah responden secara proporsional $(10 \%)$ dari populasi. Kuesioner yang disusun untuk memperoleh data primer terdiri atas 71 pertanyaan untuk mendapat informasi mengenai karakteristik individu pembudidaya ikan $\left(\mathrm{X}_{1}\right)$, dukungan input output produksi $\left(\mathrm{X}_{2}\right)$, dukungan penyuluhan $\left(\mathrm{X}_{3}\right)$ dan kompetensi pembudidaya ikan (Y). Uji validitas dan reliabilitas instrumen penelitian dilakukan pada pembudidaya di Kecamatan Genteng, Banyuwangi. Hasil uji coba memperlihatkan bahwa kuesioner layak digunakan dengan nilai uji validitas sebesar 0,362 - 0,951 dan nilai uji reliabilitas sebesar $0,421-0,950$.

Data kualitatif mengenai perkembangan kondisi budidaya ikan dan teknis budidaya ikan lele didapat dari Dinas Kelautan dan Perikanan Kabupaten Banyuwangi dan P2MKP (Pusat Pelatihan Mandiri Kelautan dan Perikanan) Raja Lele Muncar. Data dianalisis menggunakan Regresi Linear Berganda, menggunakan program SPSS 16. Sebelum data diolah menggunakan mode regresi, dilakukan transformasi data dengan rumus berikut (Sumardjo, 1999):

$$
\text { Indeks Transformasi }=\frac{\text { Jumlah skor yang diperoleh setiap indikator }- \text { jumlah skor terkecil } \times 100}{\text { Jumlah skor maksimum }- \text { jumlah terkecil }}
$$

Model persamaan regresi linear berganda yang diuji:

$$
\mathrm{Y}=\mathrm{b} 0+\mathrm{b} 1 \mathrm{X} 1+\mathrm{b} 2 \mathrm{X} 2+\mathrm{b} 3 \mathrm{X} 3+\ldots+\mathrm{bnXn}
$$

Keterangan:

$\mathrm{Y} \quad=$ variabel terikat

$\mathrm{Xi} \quad=$ variabel bebas ke $\mathrm{i}$, untuk $\mathrm{i}=1,2,3, \ldots \mathrm{n}$

bi $=$ koefisien regresi parsial tak baku ke $\mathrm{i}$, untuk $\mathrm{i}=1,2,3, \ldots \mathrm{n}$

b0 = intersept

\section{Hasil dan Pembahasan}

\section{Karakteristik Individu Pembudidaya Ikan}

Sebagian besar responden berusia 39-46 tahun, mayoritas pendidikan formal pembudidaya ikan tamat Sekolah Menengah Pertama (SMP), kondisi di Kabupaten Banyuwangi lebih bagus jika dibandingkan dengan di Cirebon yang jauh lebih rendah (Hariyadi, 
2014). Pendidikan non formal responden berkisar antara 3-6 kali dan termasuk dalam kategori rendah, pengalaman budidaya ikan 1-9 tahun dan tergolong dalam kategori rendah, pendapatan perbulan yang diterima oleh pembudidaya ikan termasuk dalam kategori rendah yakni Rp. 1.500.000 - Rp. 3.300.000. Jumlah pendapatan yang diterima oleh pembudidaya ikan di Kecamatan Muncar lebih besar jumlahnya jika dibandingkan dengan besaran UMR di Kabupaten Banyuwangi, jumlah tanggungan keluarga antara 3-5 orang dalam satu keluarga, sedangkan untuk skala usaha pembudidaya ikan berkisar antara 4-8 kolam.

Tabel 1 menunjukan pembudidaya ikan tergolong dalam usia dewasa atau produktif,hal ini menunjukan bahwa usaha budidaya ikan kurang diminati oleh masyarakat kalangan usia muda, ini mendukung hasil penelitian Purwayanti (2004), Aprolita etal., (2008) dan Hariyadi(2014) pembudidaya ikan didua lokasi penelitian yang berbeda masingmasing berusia dewasa dan cenderung tua. Selanjutnya pendidikan formal pembudidaya ikan dalam kategori sedang dan cenderung tinggi, mayoritas pembudidaya ikan telah mengenyam pendidikan pada Sekolah Menengah Atas (SMA) namun karena keterbatasan biaya sehingga mengharuskan untuk berhenti sekolah dan menjadi nelayan pada waktu itu, sejalan dengan Heliawaty dan Nurlina (2009) petani usia muda $<56$ tahun dengan tingkat pendidikan formal yang dicapai cenderung memiliki daya penalaran yang lebih bagus jika dibandingkan petani diusia lanjut.

Pengalaman budidaya ikan pada masyarakat Muncar masih tergolong rendah, hal ini sejalan dengan hasil penelitian Aprolita et al., (2008), Fatchiya (2010), Hariyadi (2014) menegaskan bahwa mayoritas pengalaman pembudidaya ikan masih tergolong rendah dan hanya didukung dengan kemampuan teknis saja. Berbeda dengan hasil penelitian Koten (2015) mayoritas pembudidaya ikan di Kabupaten Minahasa Utara memiliki pengalaman budidaya yang tinggi. Jumlah tanggungan keluarga termasuk dalam kategori sedang, hal ini mendukung hasil penelitian Iliyasu (2016) bahwa jumlah tanggungan keluarga pada

Tabel 1. Jumlah dan Persentase Responden berdasarkan Karakteristik Individu

\begin{tabular}{|c|c|c|c|}
\hline Karakteristik Individu & Kategori & $\begin{array}{l}\text { Jumlah } \\
\text { (Orang) }\end{array}$ & $\begin{array}{c}\text { Persentase } \\
(\%)\end{array}$ \\
\hline \multirow{3}{*}{$\begin{array}{l}\text { Usia (Tahun) } \\
\text { (Rataan = 43 Tahun) } \\
\text { (Std. Deviasi = 4,67) }\end{array}$} & Muda (30-38) Tahun & 3 & 6 \\
\hline & Dewasa (39-46) Tahun & 33 & 69 \\
\hline & Tua $(>47)$ Tahun & 12 & 25 \\
\hline \multirow{3}{*}{$\begin{array}{l}\text { Pendidikan Formal } \\
(\text { Rataan }=9 \text { Tahun }) \\
(\text { Std. Deviasi }=1,48)\end{array}$} & Rendah (6-8) Tahun & 1 & 2 \\
\hline & Sedang (9-11) Tahun & 33 & 69 \\
\hline & Tinggi (12-13) Tahun & 14 & 29 \\
\hline \multirow{3}{*}{$\begin{array}{l}\text { Pendidikan Non Formal (Kali) } \\
(\text { Rataan }=6 \text { Kali) } \\
(\text { Std. Deviasi }=3,28)\end{array}$} & Rendah (3-6) Kali & 26 & 54 \\
\hline & Sedang (7-9) Kali & 11 & 23 \\
\hline & Tinggi (10-12) Kali & 11 & 23 \\
\hline \multirow{3}{*}{$\begin{array}{l}\text { Pengalaman Budidaya } \\
\text { (Rataan= } 4,7 \text { Tahun) } \\
(\text { Std. Deviasi = 3,38) }\end{array}$} & Rendah (1-9) Tahun & 45 & 94 \\
\hline & Sedang (10-17) Tahun & 2 & 4 \\
\hline & Tinggi $(>18)$ Tahun & 1 & 2 \\
\hline \multirow{3}{*}{$\begin{array}{l}\text { Pendapatan (Bulan) } \\
(\text { Rataan = Rp.2.591.304) } \\
(\text { Std. Deviasi = 674.208) }\end{array}$} & Rendah (Rp.1.500.000-Rp.3.300.000) & 44 & 92 \\
\hline & Sedang (Rp.3.400.000-Rp.5.100.000) & 2 & 4 \\
\hline & Tinggi (Rp.5.100.000-Rp. 7.000.000) & 2 & 4 \\
\hline \multirow{3}{*}{$\begin{array}{l}\text { Tanggungan Keluarga } \\
\text { (Rataan = } 4 \text { Orang) } \\
(\text { Std. Deviasi = 1) }\end{array}$} & Rendah (1-2) Orang & 1 & 2 \\
\hline & Sedang (3-5) Orang & 39 & 81 \\
\hline & Tinggi (6-8) Orang & 8 & 17 \\
\hline \multirow{3}{*}{$\begin{array}{l}\text { Skala Usaha } \\
(\text { Rataan }=7 \text { Kolam }) \\
(\text { Std. Deviasi }=2,04\end{array}$} & Kecil (4-8) Kolam & 31 & 65 \\
\hline & Sedang (9-13) Kolam & 16 & 33 \\
\hline & Besar (14-18) Kolam & 1 & 2 \\
\hline
\end{tabular}

Keterangan: $n=48$, seluruh pengelompokkan karakteristik individu didasarkan kepada sebaran responden 
pembudidaya ikan di semenanjung Malaysia termasuk dalam kategori sedang dan cenderung memiliki pengaruh terhadap keputusan usaha budidaya ikan.

Pendapatan yang diterima oleh pembudidaya ikan mengalami peningkatan jika dibandingkan dengan sebelumnya yakni Rp. 1.750.000,- dari hasil bekerja sebagai nelayan dengan rata-rata pendapatan sebesar Rp. 2.591.304,- hal ini disebabkan oleh adanya sistem bagi hasil yang kurang mebguntungkan bagi awak kapal sehingga pendapatan yang dapat dibawa pulang hanya sedikit. Hal serupa ditemukan oleh Kohar dan Bambang (2009) dan Putri (2014) bahwa pendapatan pembudidaya ikan pada lahan pasang surut secara signifikan meningkat dan menurunkan angka kemiskinan. Nelayan di Kecamatan Muncar sebagian besr telah mengenal program $\mathrm{KB}$, hal ini terlihat dari jumlah tanggungan keluarga dengan rata-rata empat orang per keluarganya.

\section{Dukungan Input Output Produksi}

Modal yang digunakan oleh pembudidaya ikan tergolong dalam kategori sedang dan cenderung rendah mengingat skala usaha budidaya ikan yang digeluti masih tergolong kecil. Tenaga kerja yang digunakan dalam usaha budidaya ikan sebagian besar berasal dari keluarga pembudidaya ikan sendiri. Tabel 2 menunjukan dukungan input ouput produksi cukup baik dalam mendukung usaha budidaya ikan di Kecamatan Muncar.
Ketersediaansaranainputmaupunoutputproduksi secara umum telah tersedia dengan baik di Kecamatan Muncar, namun demikian pada aspek permodalan sumber modal mayoritas berasal dari simpanan pembudidaya ikan, ini disebabkan karena sulitnya mengakses modal dari lembaga keuangan setempat, hal ini memperkuat hasil penelitian Koten (2015) mayoritas pembudidaya ikan diwilayah Kabupaten Minahasa Utara lebih memilih untuk menggunakan modal pribadi dari pada melakukan peminjaman ke bank. Jumlah modal yang dikeluarkan oleh pembudidaya ikan akan mempengaruhi jumlah pendapatan yang akan diterima nantinya. Secara keseluruhan sarana produksi perikanan termasuk dalam kategori sedang yakni $85 \%$, hal ini dikarenakan sarana produksi perikanan di Kecamatan sudah tersedia cukup baik yakni $90 \%$ sarana produksi perikanan tersedia dilokasi budidaya, sehingga pembudidaya ikan tidak perlu kesulitan untuk mendapatakan sarana produksi perikanan tersebut, hal ini mendukung hasil penelitian Syufri (2005), Andriyani (2008), dan Metalisa (2014) usaha budidaya perikanan sangat banyak memerlukan sarana produksi perikanan dan dukungan modal yang cukup sehingga dapat mempermudah dalam menerapkan teknologi yang ada, seperti penggunaan kolam fiber, sertapengembangan usaha budidaya ikan dengan sistem bioflok.

\section{Dukungan Penyuluhan Perikanan Budidaya}

Dukungan berupa penyuluhan dalam konteks pengembangan kompetensi pembudidaya ikan masih

Tabel 2. Jumlah dan Persentase Dukungan Input Output Produksi

\begin{tabular}{llrr}
\hline \multicolumn{1}{c}{$\begin{array}{c}\text { Dukungan Input Output } \\
\text { Produksi }\end{array}$} & Kategori & $\begin{array}{r}\text { Jumlah } \\
\text { (Orang) }\end{array}$ & $\begin{array}{c}\text { Persentase } \\
\text { (\%) }\end{array}$ \\
\hline Modal & Rendah (Rp.7.500.000-Rp.10.999.999) & 17 & 35 \\
(Rataan= Rp. 13.626.041) & Sedang (Rp.11.000.000-Rp. 15.999.999) & 20 & 42 \\
(Std. Deviasi = 9.867.580) & Tinggi (Rp.16.000.000-Rp.17.500.000) & 11 & 23 \\
Sarana produksi perikanan & Rendah (15-18) & 3 & 6 \\
(Rataan =19,9) & Sedang (18-21) & 41 & 85 \\
(Std. Deviasi =1,217) & Tinggi (22-24) & 4 & 8 \\
Tenaga kerja & Rendah (4-6) & 37 & 77 \\
(Rataan =6,2) & Sedang (7-9) & 4 & 8 \\
(Std. Deviasi =1,464) & Tinggi (10-12) & 7 & 15 \\
Ketersediaan pasar & Rendah (10-13) & 2 & 4 \\
(Rataan =17,4) & Sedang (14-16) & 11 & 23 \\
(Std. Deviasi =2,369) & Tinggi (17-19) & 35 & 73 \\
\hline
\end{tabular}

Keterangan: $\mathrm{n}=48$ 
terbatas. Hal ini dapat dilihat dari Tabel 3 bahwa metode penyuluhan kurang variatif (lebih banyak ceramah dan pertemuan, kurang praktik), dengan pilihan materi terbatas (lebih banyak teknis budidaya daripada aspek manajerial dan pengembangan pasar), dan intensitas penyuluhan rendah sampai sedang (per tiga bulan sekali).

Tabel 3. Kategori dan Persentase Dukungan Penyuluhan Budidaya

\begin{tabular}{|c|c|c|c|}
\hline $\begin{array}{c}\text { Dukungan } \\
\text { Penyuluhan } \\
\text { Perikanan Budidaya }\end{array}$ & $\begin{array}{l}\text { Kategori } \\
\text { (Skor) }\end{array}$ & $\begin{array}{l}\text { Jumlah } \\
\text { (Orang) }\end{array}$ & $\begin{array}{c}\text { Persen } \\
(\%)\end{array}$ \\
\hline \multirow{3}{*}{$\begin{array}{l}\text { Metode Penyuluhan } \\
(\text { Rataan }=7,02) \\
(\text { Std. Deviasi }=1,631)\end{array}$} & $\begin{array}{l}\text { Kurang } \\
\text { variatif }(5-8)\end{array}$ & 46 & 96 \\
\hline & Cukup (9-11) & 1 & 2 \\
\hline & $\begin{array}{l}\text { Sangat variatif } \\
(12-15)\end{array}$ & 1 & 2 \\
\hline \multirow{3}{*}{$\begin{array}{l}\text { Materi Penyuluhan } \\
(\text { Rataan }=8,71) \\
(\text { Std. Deviasi }=2,073)\end{array}$} & Terbatas (5-9) & 23 & 48 \\
\hline & $\begin{array}{l}\text { Memadai } \\
(10-14)\end{array}$ & 24 & 50 \\
\hline & $\begin{array}{l}\text { Banyak pilihan } \\
(15-19)\end{array}$ & 1 & 2 \\
\hline \multirow{3}{*}{$\begin{array}{l}\text { Intensitas Penyuluhan } \\
(\text { Rataan }=7,2) \\
(\text { Std. Deviasi }=1,387)\end{array}$} & Rendah (4-6) & 15 & 31 \\
\hline & Sedang (7-9) & 28 & 58 \\
\hline & Tinggi (10-12) & 5 & 10 \\
\hline
\end{tabular}

Keterangan: $\mathrm{n}=48$

Metode penyuluhan yang banyak digunakan adalah ceramah yakni sebanyak $78 \%$, selanjutnya adalah kunjungan lapang 16\% dan demplot sebanyak $6 \%$ (Gambar 1). Penggunaan metode ceramah pada penyuluhan akan lebih tepatnya digunakan diawal, selebihnya adalah dengan melakukan demplot dan kunjungan lapang. Secara umum materi penyuluhan berupa teknis produksi ikan dan perencanaan usaha budidaya termasuk dalam kategori sedang yakni sebanyak $50 \%$ pembudidaya ikan menyatakan bahwa materi yang diberikan oleh penyuluh perikanan telah sesuai dengan permasalahan yang ada, selain itu penyuluh perikanan juga menyampaikan materi yang telah disesuaikan dengan kebutuhan yang ada dilapangan, hal ini sejalan dengan penelitian Hengky (2015) materi penyuluhan yang diberikan kepada masyarakat petani ikan disesuaikan dengan potensi dan prospek budidaya ikan kedepan. Secara umum intensitas penyuluhan pada masyarakat pembudidaya ikan di Kecamatan Muncar Kabupaten Banyuwangi termasuk dalam kategori sedang yakni sebesar 58\%, hal ini disebabkan oleh frekuensi kehadiran penyuluh perikanan masih tergolong jarang, selain itu penyuluh perikanan minim sekali tingkat kehadirannya dilokasi binaan penyuluh tersebut. Hal ini sejalan dengan hasil penelitian Purwayanti (2004) intensitas penyuluhan yang dilakukan oleh penyuluh perikanan diwilayah Kecamatan Cipaku Kabupaten Ciamis termasuk dalam kategori sedang, hal ini disebabkan oleh minimnya jumlah tenaga penyuluh perikanan pada daerah tersebut.

\section{Kompetensi Usaha Budidaya}

Secara keseluruhan kompetensi usaha budidaya pada aspek merencanakan produksi manajerial dan aspek produksi sudah cukup baik, namun demikian pada aspek pemasaran masih termasuk dalam kategori rendah, hal ini disebabkan oleh masih lemahnya kemampuan pembudidaya ikan dalam rangka ikut menentukan harga ikan di pasaran.

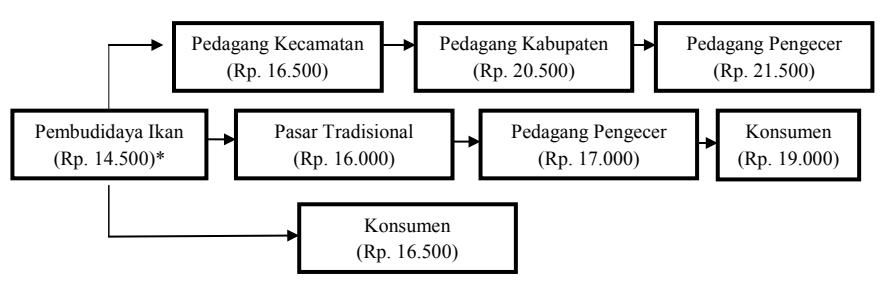

*harga yang berlaku pada saat penelitian berlangsung

\section{Gambar 1. Rantai Pemasaran Ikan Lele di Kecamatan Muncar}

Terdapat 3 saluran pemasaran hasil budidaya ikan lele dari Muncar (Gambar 1). Mayoritas pembudidaya ikan menjual melalui pedagang pengumpul di tingkat kecamatan sebanyak 75\%; penjualan melalui pasar tradisional sebanyak $15 \%$ dan 10\% langsung ke konsumen. Pembudidaya ikan lebih memilih menjual ikan lele ke pedagang pengumpul di daerah karena lebih mudah dan telah mempunyai hubungan baik antara ke duanya (patron client). Pedagang pengumpul merupakan patron bagi pembudidaya dalam bentuk pemberian bantuan modal dan sarana produksi.

Jumlah share margin yang terbentuk dari adanya penjualan ikan lele cukup banyak menguntungkan pihak pengumpul/tengkulak, hal ini terlihat pada masingmasing saluran pemasaran (Gambar 1) pedagang 
pengumpul di tingkat kabupaten mendapatkan share margin sebanyak paling tinggi yakni Rp. 4.000,- pada setiap $\mathrm{kg}$ hasil penjualan dari pembudidaya ikan, hal ini sangat berbeda jauh jika dibandingkan dengan share margin yang diterima oleh pembudidaya ikan dengan menjual langsung budidaya ikan pada konsumen dengan share margin yang diterima sebesar Rp. 2.000,- pada setiap $\mathrm{kg}$ hasil penjualan ikan.

Pada aspek manajerial, pembudidaya ikan telah mampu merencanakan usaha, mengontrol dan mengembangkan usaha dengan baik (Tabel 4). Temuan ini berbeda dengan Mardiana (2015) yang menyatakan bahwa kemampuan manajerial usaha pembudidaya ikan patin di Desa Kabupaten Minahasa Utara masih sangat rendah. Lemahnya kompetensi pembudidaya ikan dalam pemasaran yakni daya tawar dan akses pasar dipengaruhi oleh kuatnya pengaruh pedagang ikan lele setempat (tengkulak) dalam menentukan harga ikan. Ketika musim panen ikan tiba, pembudidaya ikan tidak dapat menentukan harga ikan. Hal ini disebabkan dalam menjalankan usaha budidaya ikan pembudidaya belum dapat melakukan penghematan uang dari hasil budidaya dan cenderung digunakan untuk pemenuhan kebutuhan yang bersifat konsumtif, sehingga pada saat musim tebar, pembudidaya ikan kembali melakukan pinjaman modal pada patron dengan varian pinjaman berupa modal usaha ataupun sarana produksi perikanan.

\section{Faktor yang Berpengaruh terhadap Kompetensi Budidaya}

Hasil analisis regresi (Tabel 5) memperlihatkan

Tabel 4. Kategori dan Persentase Kompetensi Usaha Budidaya

\begin{tabular}{|c|c|c|c|}
\hline Kompetensi Usaha Budidaya & Kategori Skor & Jumlah (Orang) & Persentase $(\%)$ \\
\hline \multirow{3}{*}{$\begin{array}{l}\text { Merencanakan Produksi } \\
(\text { Rataan }=19,3) \\
(\text { Std. Deviasi }=2,32)\end{array}$} & Rendah (14-17) & 9 & 19 \\
\hline & Sedang (18-21) & 21 & 44 \\
\hline & Tinggi (22-25) & 18 & 38 \\
\hline \multirow{3}{*}{$\begin{array}{l}\text { Mengontrol Usaha } \\
(\text { Rataan }=12,6) \\
(\text { Std. Deviasi }=1,82)\end{array}$} & Rendah (8-10) & 7 & 15 \\
\hline & Sedang (11-13) & 12 & 25 \\
\hline & Tinggi (14-16) & 29 & 60 \\
\hline \multirow{3}{*}{$\begin{array}{l}\text { Mengembangkan Usaha } \\
(\text { Rataan }=11,9) \\
(\text { Std. Deviasi }=2,57)\end{array}$} & Rendah (5-9) & 8 & 17 \\
\hline & Sedang (10-13) & 24 & 50 \\
\hline & Tinggi (14-18) & 16 & 33 \\
\hline Pemeliharaan Kolam & Rendah (6-8) & 11 & 23 \\
\hline$($ Rataan $=9,4)$ & Sedang (9-11) & 28 & 58 \\
\hline$($ Std. Deviasi = 1,56) & Tinggi (12-14) & 9 & 19 \\
\hline Pemberian Pakan & Rendah (5-7) & 5 & 10 \\
\hline$($ Rataan $=10,3)$ & Sedang (8-10) & 15 & 31 \\
\hline$($ Std. Deviasi $=0,95)$ & Tinggi (11-12) & 28 & 58 \\
\hline Pengendalian Hama Penyakit & Rendah (8-9) & 8 & 17 \\
\hline$($ Rataan $=10,3)$ & Sedang $(10-11)$ & 15 & 31 \\
\hline$($ Std. Deviasi = 0,953) & Tinggi (12-13) & 25 & 52 \\
\hline Pemanenan & Rendah (6-8) & 9 & 19 \\
\hline$($ Rataan $=9,8)$ & Sedang (9-11) & 22 & 46 \\
\hline$($ Std. Deviasi $=1,45)$ & Tinggi (12-14) & 17 & 35 \\
\hline Daya Tawar & Rendah (3-4) & 31 & 65 \\
\hline$($ Rataan $=4,4)$ & Sedang (5-6) & 7 & 15 \\
\hline$($ Std. Deviasi $=1,25)$ & Tinggi (7-8) & 10 & 21 \\
\hline Akses Pasar & Rendah (5-7) & 27 & 56 \\
\hline$($ Rataan $=7,3)$ & Sedang (8-10) & 17 & 35 \\
\hline$($ Std. Deviasi =1,62) & Tinggi (11-13) & 4 & 8 \\
\hline
\end{tabular}

Keterangan: $\mathrm{n}=48$ 
Tabel 5. Koefisien Regresi Karakteristik Individu, Dukungan Input Ouput Produksi dan Dukungan Penyuluhan

\begin{tabular}{|c|c|c|c|c|c|c|c|c|}
\hline \multirow{2}{*}{ Variabel } & \multicolumn{2}{|c|}{$\mathbf{Y}$} & \multicolumn{2}{|c|}{$\begin{array}{c}Y_{1.1} \\
\text { (Manajerial) }\end{array}$} & \multicolumn{2}{|c|}{$\begin{array}{c}\mathrm{Y}_{1.2} \\
\text { (Produksi) }\end{array}$} & \multicolumn{2}{|c|}{$\begin{array}{c}\mathbf{Y}_{1.3} \\
\text { (Pemasaran) }\end{array}$} \\
\hline & $\beta$ & $\begin{array}{c}P \\
\text { Value }\end{array}$ & $\beta$ & $\begin{array}{c}\mathbf{P} \\
\text { Value }\end{array}$ & B & $\begin{array}{c}\mathbf{P} \\
\text { Value }\end{array}$ & $\beta$ & $\begin{array}{c}\mathbf{P} \\
\text { Value } \\
\end{array}$ \\
\hline \multicolumn{9}{|l|}{ Karakteristik Individu (X1) } \\
\hline Usia (X1.1) & $-0,179$ & 0,141 & $-0,222$ & 0,118 & $-0,216$ & 0,107 & 0,158 & 0,375 \\
\hline Pendidikan Formal (X1.2) & 0,121 & 0,283 & 0,096 & 0,465 & 0,060 & 0,629 & 0,287 & 0,088 \\
\hline Pendidikan Non Formal (X1.3) & 0,095 & 0,406 & 0,187 & 0,165 & 0,098 & 0,437 & $-0,194$ & 0,252 \\
\hline Pengalaman Budidaya (XI.4) & $-0,065$ & 0,502 & $-0,087$ & 0,441 & $-0,042$ & 0,690 & $-0,038$ & 0,788 \\
\hline Pendapatan (X1.5) & 0,187 & 0,320 & 0,178 & 0,418 & 0,238 & 0,251 & $-0,071$ & 0,796 \\
\hline Tanggungan Keluarga (X1.6) & 0,265 & 0,170 & 0,245 & 0,056 & $0,298^{*}$ & 0,015 & 0,340 & 0,831 \\
\hline Skala Usaha (X1.7) & 0,043 & 0,792 & 0,000 & 0,996 & $-0,025$ & 0,887 & 0,325 & 0,180 \\
\hline Dukungan Input Output Produksi (X2) & $0,254^{*}$ & 0,031 & $0,317 *$ & 0,022 & 0,241 & 0,061 & $-0,027$ & 0,873 \\
\hline Dukungan Penyuluhan (X3) & $0,372 *$ & 0,004 & 0,260 & 0,075 & $0,406^{*}$ & 0,004 & 0,279 & 0,129 \\
\hline
\end{tabular}

*Signifikan pada $\alpha=0,05 ; \mathrm{n}=48$

bahwa usia, pendidikan formal, pendidikan non formal, pengalaman budidaya, pendapatan dan skala usaha tidak berpengaruh terhadap kompetensi pembudidaya ikan. Dukungan input - output produksi dan dukungan penyuluhan berpengaruh positif terhadap kompetensi usaha budidaya ikan pada aspek manajerial, dan aspek produksi.

\section{Kompetensi Usaha Budidaya}

Dukungan input output produksi berpengaruh nyata terhadap kompetensi usaha budidaya ikan, hal ini terlihat dari terpenuhinya kebutuhan sarana dan produksi perikanan di Kecamatan Muncar ini. Kebutuhan tenaga kerja untuk usaha budidaya ikan juga dapat terpenuhi, namun dari segi permodalan, pembudidaya ikan masih kesulitan mengakses modal usaha. Dukungan penyuluhan juga berpengaruh nyata terhadap kompetensi usaha budidaya ikan. Dalam hal ini, penyuluh swadaya dan penyuluh perikanan bantu turut berperan dalam menyosialisasikan usaha budidaya dan pelatihan dasar budidaya ikan lele. Hal serupa dijumpai pula dalam usaha budidaya patin di Jambi (Aprolita et al., 2008) dan kasus petani padi di Sulawesi Selatan (Sapar, 2012) yang memperlihatkan bahwa penyuluh turut andil dalam memberikan masukan bagi pembudidaya dan petani terkait isu yang dihadapi.

\section{Kompetensi Manajerial}

Pada aspek dukungan input output produksi komponen yang memiliki pengaruh cukup signifikan adalah modal dan sarana produksi perikanan, semakin tinggi modal yang digunakan oleh masyarakat pembudidaya ikan menunjukkan bahwa kemampuan akses permodalan yang dimiliki oleh pembudidaya ikan semakin kuat. Hal ini sejalan dengan hasil penelitian Surahmat (2009) menyatakan bahwa usaha pembenihan ikan bawal air tawar di Cibungbulang Kabupaten Bogor menjadi cepat berkembang jika didukung dengan modal pinjaman dari lembaga keuangan. Serta didukung dengan hasil penelitian Koten (2015) pembudidaya ikan di Kabupaten Minahasa Utara belum dapat mengakses permodalan dari luar sehingga menyebabkan usaha budidaya ikannya mengalami stagnasi. Berbeda dengan hasil penelitian Aprolita et al., (2008) kemampuan pembudidaya ikan patin dilahan gambut Kabupaten Muaro Jambi masih dalam kategori sangat rendah, karena pinjaman modal yang berasal dari perbankan hanya diperuntukkan untuk beberapa orang saja.

\section{Kompetensi Produksi}

Jumlah tanggungan keluarga masyarakat pembudidaya ikan berpengaruh positif terhadap produksi ikan lele. Hal ini dikarenakan, pembudidaya ikan di Muncar menggunakan tenaga kerja dalam keluarga dalam usahanya. Sehingga dengan semakin banyaknya anggota keluarga dalam usaha, maka semakin banyak kolam yang dikelola, dan produksi meningkat. 
Dukungan input output produksi memiliki pengaruh yang signifikan terhadap kompetensi usaha produksi, hal ini terjadi karena kebutuhan sarana dan prasarana budidaya ikan mudah diperoleh secara langsung di Kecamatan Muncar. Dukungan penyuluhan yang diberikan oleh penyuluh perikanan swadaya maupun penyuluh perikanan bantu, sebagian besar materi yang diberikan berupa pengetahuan teknis produksi budidaya ikan lele, materi inilah yang sering digunakan secara berulang-ulang oleh penyuluh. Pada aspek teknis budidaya pembudidaya ikan sudah cukup menguasai, hal ini disebabkan oleh keaktifan pembudidaya ikan dalam berlatih secara mandiri (otodidak) kepada pembudidaya ikan yang telah berhasil.

\section{Kesimpulan}

Kompetensi manajerial dan kompetensi dalam teknis produksi pembudidaya ikan lele berada dalam kategori tinggi, namun tergolong rendah dalam posisi tawar menawar harga hasil produksi. Dukungan input ouput produksi perikanan dan ketersediaan layanan penyuluhan perikanan berpengaruh positif nyata terhadap kompetensi pembudidaya ikan. Jumlah tanggungan keluarga berpengaruh positif terhadap produksi.

Guna meningkatkan kemampuan pembudidaya dalam posisi tawar jual ikan lele, diperlukan wadah berupa lembaga yang memiliki kekuatan dalam bernegosiasi harga dengan pembeli/pengumpul. Lembaga tersebut dapat berbentuk Koperasi atau bentuk lain yang sesuai dengan kebutuhan pembudidaya. Lembaga penyuluhan perikanan di tingkat kecamatan perlu diperkuat dan dikembangkan eksistensinya, di antaranya melalui penambahan jumlah dan kualitas penyuluh, variasi metode dan materi penyuluhan, serta DIKLAT penyuluh dan pembudidaya yang lebih kontinyu.

\section{Daftar Pustaka}

Adam L. 2012 Kebijakan Pengembangan Perikanan Berkelanjutan (Studi Kasus: Kabupaten Wakatobi, Provinsi Sulawesi Tenggara dan Kabupaten Pulau Morotai, Provinsi Maluku Utara. Jurnal Perikanan dan Kelautan. 2(2). [Diunduh Mei 2015]

Andriyani R. 2008. Kelayakan dan Strategi Pengembangan Usaha Kelompok Pembudidaya Ikan Melalui Program Replika SKIM Modal Kerja (Studi Kasus Kelompok Tani Ikan Mekar Jaya di
Lido, Bogor). [tesis]. Bogor (ID): Institut Pertanian Bogor.

Aprolita, Amanah S, Susanto D. 2008. Kemandirian Pembudidaya Ikan Patin di Lahan Gambut di Desa Tangkit Baru, Kecamatan Kumpe Ulu Kabupaten Muaro Jambi Provinsi Jambi. Jurnal Penyuluhan. 4 (2): 126-134 [Diunduh Mei 2016]

Fatchiya A. 2010. Tingkat Kapasitas Pembudidaya Ikan dalam Mengelola Usaha Akuakultur secara Berkelanjutan. Jurnal Penyuluhan. 6(11). [Diunduh Februari 2016]

Hariyadi I, Amanah S, Suriatna S. 2014. Persepsi Pembudidaya Ikan Terhadap Kompetensi Penyuluh Perikanan di Kawasan Minapolitan (Kasus di Kabupaten Cirebon, Provinsi Jawa Barat). Jurnal Penyuluhan. 10(2): 123-130 [Diunduh Juni 2016]

Heliawaty N. 2009. Sikap Petani Kakao terhadap Penerapan Metode PsPSP dalam Rangka Peningkatan Produktifitas dan Kualitas Biji Kakao. Jurnal Agrisistem 5(1). ISSN2089-0036. [Diunduh Februari 2016]

Hengky S, Watung J. 2015. IPTEK bagi masyarakat (IbM) kelompok petani ikan di Desa Eris, Kecamatan Eris, Kabupaten Minahasa. Jurnal Budidaya Perairan. 3(7). [Diunduh Mei 2016]

Iliyasu A, Mohamed ZA, Terano R. 2016. Comaparative Analysis of Technical Efficiency for Different Production Culture System and Species of Freshwater Aquaculture in Peninsular Malaysia. Science Direct Aquaculture Reports. 3(4). [Diunduh Juni 2016]

Koten E, Mondoringin L, Salinhedo IRN. 2015. Evaluasi Usaha Pembudidaya Ikan di Desa Matungkas Kabupaten Minahasa Utara. Jurnal Budidaya Perairan. 3(1). [Diunduh Mei 2016]

Kohar M, Bambang AW. 2009. Dampak Pengembangan Perikanan Budidaya terhadap Penurunan Kemiskinan, Peningkatan Pendapatan dan Penyerapan Tenaga Kerja di Jawa Tengah. Penelitian Bidang Budidaya. Jurnal Ilmu-ilmu Sosial. 2(3): 22-34. [Diunduh April 2016]

Kusumastanto T. 2008. Kebijakan dan Strategi Peningkatan Daya Saing Produk Perikanan Indonesia. Pusat Kajian Sumberdaya Pesisir dan Lautan. Bogor (ID): Institut Pertanian Bogor.

LAKIP KKP. 2014. Laporan Akuntabilitas Kinerja Kementeria Kelautan dan Perikanan. Jakarta (ID): Kementerian Kelautan dan Perikanan.

Purwayanti D. 2004. Kemandirian Usaha Pembudidaya 
Ikan dalam Proyek Pembinaan Peningkatan Pendapatan Petani - Nelayan Kecil (P4K) Di Desa Muktisari, Kecamatan Cipaku, Kabupaten Ciamis. [skripsi]. Bogor (ID): Institut Pertanian Bogor.

Mardiana, Winda M, Hengky S. 2015. Kajian Kelayakan dan Pengembangan Lahan Budidaya Kepiting Bakau (Scylla spp) di Desa Kabupaten Minahasa Utara. Jurnal Budidaya Perairan.3(1). [Diunduh Juni 2016]

Metalisa R, Saleh A, Tjiptopranoto P. 2014. Peran Ketua Kelompok Wanita Tani dalam Pemanfaatan Lahan Pekarangan yang Berkelanjutan. Jurnal Penyuluhan. 10(2). [Diunduh Juni 2016]

Neuman WL. 2000. Social Research Methods. Qualitative and Quantitative Approaches. Allyn and Bacon. Boston.

Putri, Tike D, Priadi, Dwi P, Sriati. 2014. Dampak Usaha Perikanan Budidaya terhadap Kondisi Lingkungan dan Sosial Ekonomi Masyarakat Pada Lahan Pasang Surut Kabupaten Banyuasin Propinsi Sumatera Selatan. Jurnal Akuakultur Rawa Indonesia. 2(1): 43-54. [Diunduh Juli 2016]

Spencer LM, Spencer SM. 1993. Competence At Work: Models for Superior Performance. NewYork (US): John Wiley and Sons, Inc.

Sumardjo. 1999. Transformasi Model Penyuluhan Pertanian Menuju Pengembangan Kemandirian Petani: Kasus di Propinsi Jawa Barat. [disertasi]. Bogor (ID): Institut Pertanian Bogor.

Syufri A. 2005. Pemberdayaan Nelayan Tradisional Kasus Penyuluhan di Sepanjang Pantai Kota Padang. Bogor (ID): Institut Pertanian Bogor.

Vazirani N. 2010. Competencies and Competency Model-A Brief overview of its Development and Application. SIES Journal of Management. 7(1): 121-131. [Diunduh Agustus 2016]

Widakdo DSWPJ. 2014. Strategi Peningkatan Kinerja Penyuluh Pertanian dalam P e $\mathrm{n} g$ e $\mathrm{m}$ b a $\mathrm{n} g$ a $\mathrm{n}$ Agribisnis di Kabupaten Banyuwangi. Jurnal Penyuluhan. 10(2): 98-104. [Diunduh Juli 2016] 